\title{
6. CAREER GUIDANCE AND THE PRODUCTION OF SUBJECTIVITY
}

\begin{abstract}
Using Foucault's analytical tools this chapter explores the development of career guidance historically and contextually and examines how it is imbued with different ideologies, discourses and forms of power to produce subjectivity. The chapter identifies the emergence of five discourses and related productions of subjectivity and places these in the context of the development of guidance in Norway. These are described as the philanthropic, industrial, welfare state, neoliberal and knowledge society discourses. Finally, Nordic counter discourses are explored. The chapter argues that career guidance in Norway has a political function, that it produces forms of subjectivity and acts as a governing technology.
\end{abstract}

\section{CAREER GUIDANCE OECD AND EU}

Career guidance is often presented as both a public policy tool and as a service to the individual (Sultana, 2004). This has resulted in a range of different discourses about the importance and purpose of career guidance. This chapter focuses on examining these different discourses in relation to career guidance policy in Norway. In addition to domestic traditions of career guidance, Norway's approach to career guidance and the discourses that are used in policy have been influenced over a number of decades by the Organisation for Economic Co-operation and Development (OECD, 2004, 2014) and the European Union (EU) (European Commission, 2004, 2008; OECD, 2004, 2014). It is therefore important to explore the ideas of these international organisations when examining Norwegian career guidance.

In Europe, the EU and the OECD have shaped the definition of career guidance and developed a range of policy rationales for its use. The EU, in its 2004 resolution, states: 'High quality guidance provision throughout life is a key component of education, training and employability strategies to attain the strategic goal of Europe becoming the world's most dynamic knowledge based society by 2010' (European Commission, 2004, p. 3). In 2004 the OECD defined career guidance in the following way:

Career guidance refers to services and activities intended to assist individuals, of any age and at any point throughout their lives, to make educational, training and occupational choices and to manage their careers ... The activities may 
take place on an individual or group basis, and may be face-to-face or at a distance (including help lines and web-based services). They include career information provision (in print, ICT-based and other forms), assessment and self-assessment tools, counseling interviews, career education programmes (to help individuals develop their self awareness, opportunity awareness, and career management skills), taster programmes (to sample options before choosing them), work search programmes, and transition services. (OECD, 2004, p. 11)

The OECD's definition is both concrete and comprehensive. It is concrete in that career guidance deals with questions related to education and work. It says what career guidance consists of and states that its aim is to contribute to the lifelong development of the individual's career. The OECD concretises career guidance by discussing it in terms of its relationships with context, the activities that are undertaken as part of career guidance and by pointing out the importance of selfmanagement techniques. The EU, focuses on discourses of the knowledge society and of global competitiveness, by linking career guidance to 'employability' and career management skills (CMS) (European Commission, 2004). At the same time, we see that the OECD emphasises the notion of the informed, self- and labour market-aware subject as the imagined recipient of career guidance. The EU and OECD documents imply that the practice of career guidance is primarily based in economic, psychological and pedagogical knowledge. Career guidance thus emerges with a heterogeneous identity.

In order to show that career guidance has not always been justified in the ways that OECD and EU have argued, this chapter will consider the historical and contextual background in Norway which gave birth to modern career guidance when it was established in the early 1900s. The analysis draws on Michel Foucault's analytical framework.

\section{FOUCAULT'S ANALYTICAL CONCEPTS}

Michel Foucault (1926-1984) is known for his controversial and provocative analyses of how modern man has understood himself and how this understanding is always connected to interventions of power (Mik-Meyer \& Villadsen, 2007). Foucault's analyses of discourse and power, inspired by the field of poststructuralism, shift the focus from 'essence to constitutive process'(Søndergaard, 2000), or from an ontological standpoint to an epistemological one (Foucault, 1973). Foucault provides critical perspectives and concepts which this chapter will use; these include discourse, power and the production of subjectivity. This chapter will show that career guidance can be understood as a historically and contextually conditioned 'control practice' tied to the educational and labour market arenas (Kjærgård, 2012). 
Foucault's (1973) definition of discourse is a broad; it involves more than speech, writing or text. Objects and subjects are viewed as the product of discursive practices and non-verbal realities such as practices and institutional frameworks that embody discourses. This framework allows us to explore how institutional procedures as power technologies that can be are used to control humans (Mik-Meyer \& Villadsen, 2007). This chapter uses Foucault's framework to examine how career guidance is increasingly justified by arguments derived from economic, juridical, psychological and pedagogical knowledge and further argues that career guidance has the potential to function as a governing technology.

\section{THE PHILANTROPIC AND PROGRESSIVE MOVEMENT AND}

THE MORAL SUBJECT

In many European countries at the end of the 18th century, there was a conflict between strict state regulation and Enlightenment beliefs in freedom and economic liberalism. The French Revolution (1789-1799) was a period of radical, social, political and economic upheavals that shook the rest of Europe (Kropotkin, 1909). In Norway at the beginning of the 19th century, state pietism was challenged internally by the Enlightenment priesthood. Demands for greater freedom emerged, not least because of the bourgeoisie's privileged position vis-à-vis the farmers. The absolute monarchy's authority was challenged by a rationalistic Christian counterculture influenced by the Haugean movement. Kristian Lofthus and Hans Nielsen Hauge emerge as two central actors who, separately, lead the movement for agricultural reform in the 19th century in Norway. Alnæs (1997) writes that they attacked systematic control from above and the role of senior state officials, as well as emotionally appealing to people's sense of justice and religious needs. In this context, Hans Nielsen Hauge is a prominent representative of the pastoral power that emerged during the Enlightenment in the fields of education and employment. They focused on worldly matters, were ethically pragmatic and worked for social liberation and access to public education. Thus, Haugenism can be regarded as the beginning of the philanthropic movement in Norway that worked for a national Enlightment. Haugenism also emerged as a pastoral power that sought to consolidate ideas of liberty, equality and fraternity, as well as individual independence, selfdetermination and moral responsibility (Alnæs, 1997).

In parallel with developments in Norway, a progressive movement emerged in the USA. Frank Parsons (1854-1908), often considered as the founder of modern career guidance (Jones, 1994), belonged to the US progressive movement (Zytowski, 2001). He saw career guidance as a social instrument, but also as an individual service that created active citizenship, hope, solidarity and harmony. He viewed career guidance as a tool for social justice in a society where the divide between the rich and the poor was widening (Davis, 1914; Riis, 1890). 
'Work and Spirit', or a religious discourse of work was a central feature of this philanthropic endeavour (Savickas, 2008, p. 99). This voluntary, friendly and informal guidance, however, developed into a programme that stressed the building of character, self-discipline, morality and responsibility (Super, 1929). Both in Norway and in the USA the focus on individual moral and ethical awareness in career guidance was anchored in a religious discourse. Work was regarded as a mission and terms such as 'calling' or 'vocation' were used. The individual's 'inner' moral response or will was decisive for 'coming to the right place' - 'Each one who listens with a responsive heart may hear the call to service’ (Davis, 1914, p. 65). The truthful and rational evaluation of occupation presented here is based in both ethics and knowledge and individuals are offered the help of an expert in making this choice. During this philanthropic and progressive period career guidance emerged as a social instrument anchored in a religious discourse with a focus on moral and ethical subjectivity.

\section{INDUSTRALISATION, PSYCHOMETRICS AND THE ADAPTABLE SUBJECT}

The philantrophic and progressive movement with their focus on the moral subject, were at the end of the 19th century challenged by an increased confidence in scientific objectivity. Industrial growth and huge demographic changes gave birth to the first Vocational Bureau in Norway in 1897 (Arbeidsdirektoratet, 2006). Psychometrics now entered the scene as a scientific foundation for career guidance, and we see the development of scientifically orientated discourses within the field of career guidance which distances itself from 'mere speculation' by employing scientific, experimental psychology (Plant, 2009). It now became important to isolate mental and physical features so that they could be measured. The subject's features were differentiated and objectified so that they could be worked on and adjustments made to match the individual to the demands of the workplace (ibid). In Sweden, Mattsson (1984) states that it is also possible to see a connection between the interest in differential psychology and the specific psychotechnics of the emerging industrial society. The increasing division between manual and mental work corresponds, according to Mattsson (1984), with a growing interest in the differential psychology that provides scientific justification for this division. The traditional differentiations based on birth or rank and explained by theology are now replaced by a scientifically rooted rationality and discourse.

In the Norwegian context, the scope of application is related to recruitment and education within craft apprentices. In 1925, the Oslo Vocational School conducts the first psychotechnical tests, and there is specific testing of applicants for programmes for typesetters, printers and metalworkers (Knoff, 1994). In this period of industrialisation the turn to the use of psychometrics constructs the ideal subject as someone who is adaptable to the need of the industry and workplaces. 


\section{THE WELFARE STATE, SECURITY MECHANISM AND JUDICIAL SUBJECT POSITIONS}

Following the Second World War welfare state thinking became the key discourse that was used to discuss career guidance. Economic growth, social and financial security and equal rights for the citizens became the state's governance thinking. The citizen's needs and rights became central, and the authorities built the welfare state by constructing a number of new safety mechanisms that are understood as providing comprehensive and universal care (Foucault, 2008). Social security laws and other welfare benefits provide citizens with lifelong safety mechanisms (see Bakke, Chapter 2, this volume). The state's universalist philosophy was justified in terms of the discourse of 'scientific knowledge'. The idea of the unitary school system (enhetsskolen) in Norway, that Sverdrup espoused at the end of the 19th century, is now firmly established in the public education discourse (Sverdrup, 1884). Citizens' rights and needs are now secured through state intervention and care. We can see the contours where the ideal of the welfare state seeks to merge the collective societal culture with Christian love and humanity (Dean, 2010).

Rapid technological developments demand more specialisation, however, and in the post-war years it becomes a declared aim to create an educational system that is adapted to this more specialised labour market. Education and economic growth become part of the political agenda, and gain a political acceptance (Baune, 2007).

In 1957 a career orientation service for young people was established within the compulsory education system and became part of the welfare state's care apparatus (Kjærgård, 2012). The career guidance discourse which emerged from careers work with adults was anchored in psychology and this now met a new discourse that was based in developmental and differential psychology.

In this welfare state period a universal care discourse is dominant. The citizen's needs and rights become the central subject positions, along with the welfare state's focus on economic growth, equal rights, social and financial security.

\section{HUMAN CAPITAL, NEOLIBERALISM AND THE ECONOMIC SUBJECT}

At the end of the 20th century we see that Frank Parsons' vision of career guidance as a means of bringing about an ideal society characterised by co-operation, participation and fraternity is now almost completely replaced by neoliberal discourses in which career guidance is described as an important tool for strengthening individual competence in education, and work within an economic competition discourse.

This can be identified in Norwegian educational policy documents from the 1980 s and 1990s as a new discursive tension where education and economic growth are more closely linked. In official reports on higher education such as With knowledge and will] (NOU 1988:28, 1988) and From Vision to Action (St.meld. 
nr. 40, 1990-1991) we see the emergence of an economic and social discourse, often described as 'human capital' which is very explicit in the following statement: 'As with investment in other forms of capital, investment in knowledge capital means that incurring immediate costs will result in future gains' (St.meld.nr. 40, 1990-1991, p. 13) (Authors own translation). Education becomes an economic tool for an economic society and its competitiveness, development, wealth, welfare and destiny. People are considered in terms of their functions as consumers and employees. The individual characteristics that are favoured are the ability to make adjustments to market demands: creativity, adaptability, flexibility and the ability to acquire new knowledge and use the latest technology.

Different forms of evaluation and individualised development plans are now introduced into the public provision of career guidance. These often take the form of self-evaluation questionnaires, or what Foucault (Foucault, Martin, Gutman, \& Hutton, 1988) describes as self-governing techniques, which provide both control and self-improvement measures.

Slogans such as 'the active pupil', 'the flexible worker', 'change preparedness', 'responsibility for one's own learning' and 'guidance-ready' are concepts that transfer power, choice, responsibility and evaluation from society to the individual, from teacher to pupil, from career advisor to the individual, from career centres to their users and from institutions to individuals. Conversations, logs, files and confidentiality between pupil, teacher and advisor can in this way be regarded as tools in the individualisation strategies that create neoliberal subjects (Kjærgård, 2012). The individual is now put under pressure; he puts himself under pressure and is viewed as ever changeable in the economic discourse.

The subject can be shaped into becoming the steward of a vast array of selftechnologies and forms of self-control administered through demands for knowledge and flexibility and through their own personal morality. We can see the emergence of discourses that stress the importance of being an adaptable, useful and economic subject. In line with Bengtsson (2011), career management skills are now presented as both a strategic idea and a management technology. Firstly, the construction of career planning skills is made possible through the discourse on career planning where one's own career planning is linked to self-management and entrepreneurship. This is in line with what Rose (1998) describes as being both an active and calculating subject, one who acts and calculates in order to become a better individual. Secondly, career management skills now deal with taking responsibility for one's own career. As a control technology, career management skills involve the creation of an individual who is active, competitive, autonomous and morally responsible.

In this period a discourse emerged that is focused on economic competitiveness and within which the idea of individual competence is emphasised. Human capital and knowledge capital become central ideologies, and career management skills become a technology through which this economic subjectivity is produced. 


\section{THE KNOWLEDGE SOCIETY, CAREER MANAGEMENT SKILLS AND}

\section{THE COMPETENCE SUBJECT}

In Norway, materials such as 'Min utviklingsplan' [My development plan] (Røyland, 2011), 'Sjef I eget liv' [Boss in his own life] (Papirbredden karrieresenter, 2014), 'Karrierelæring for unge' [Career management skills-CMS] (Seville, 2017) (authors translation) are introduced into career guidance activities. They all focus on the development of career management skills, which we might also see in Foucauldian terms as self-governing technologies. This focus on career management skills is also visible in the Europeans Commission's (2008) resolution on lifelong guidance.

Career management skills play a decisive role in empowering people to become involved in shaping their learning, training and integration pathways and their careers. Such skills, which should be maintained throughout life, are based on key competences, in particular 'learning to learn', social and civic competences - including intercultural competences - and a sense of initiative and entrepreneurship. (European Commission, 2008, p. 8)

In contemporary Norwegian political discourse, the notion of career comprises both the creation and management of one's career. Management is a term that was first employed in business life and in management theory and was understood as referring to resource allocation and output control. In the 1990s, however, there was a shift within career management theories from a focus on the level of the organisation to a focus on the individual (Bengtsson, 2011). This meant that the concept of 'career' became interesting for new fields such as career development theory and political strategies for public education and public career guidance.

Lifelong learning, lifelong guidance and career planning skills are now openended activities and people are subjectified as managers of their careers throughout the course of their lives.

Career management skills are now linked to specific and virtually pre-defined competences such as 'learning to learn'. These skills are acquired through various transitional phases in life and not through a specific training programme linked to a life phase. The EU resolution of 2008 also emphasises '[...] being able to evaluate oneself, knowing oneself and being able to describe the competences one has acquired in formal, informal and non-formal education settings' (European Commission, 2008, p. 8). Through linking self-knowledge to life's multiplicity of learning arenas, competence is here made personal.

Within the discourse of the knowledge economy we see a clear focus on skills and competences in career guidance. Norway's membership of the European Lifelong Guidance Policy Network (ELGPN), has contributed to a focus on CMS in Norwegian contexts (Thomsen, 2014). The OECD has also had a great influence on the fact that in 2016 Norway got the first Official Norwegian Report (NOU 2016:7) on career guidance in Norway. Several academic articles and books on career education are 
written, both from a Nordic and Norwegian perspective (Haug, 2018; Svendsrud, 2015; Thomsen, 2014). In practice in Norway, we also see an increased focus on career education and career competence. At the secondary school there is also established a compulsory subject about Educational Choice (Utdanningsdirektoratet, 2015) (see Røise, Chapter 18, this volume).

This focus on the knowledge economy, learning and competence results in the emergence of a discursive shift in the understanding or focus of career guidance in Norway. In the OECD's (2004) definition the focus was on helping the individual to make career choices and manage his/her career through a range of activities and contexts. The emerging focus is even stronger on supporting individuals in developing specific competencies to manage their careers and the focus is worldwide, as it is also found in a number of so-called national 'blueprints': USA, National Career Development Guidelines (1989), Canada, 'Blueprint for Life/Work Designs’ (1996); Australia; Blueprint for Career Development (2001); Scotland, Career Management Skills Framework for Scotland (2012). The purpose of these initiatives is to create frameworks for a broad understanding of career guidance, where it does not solely deal with the choice of education and career, but also promotes and establishes the conditions for the learning and acquisition of career competencies (Thomsen, 2014).

According to Hooley, Watts, Sultana, and Neary (2013), these documents are the result of a series of political initiatives that build career competencies upon a learning paradigm. Thus, individual responsibility is strengthened, also in the Norwegian context.

Norsk Karriereverktøy (The Norwegian Career Tool) (Svendsrud, 2011) has a specific focus on career competence inspired by the Australian Blueprint for Career Development (Australian Government, 2001). And in 2019, a national quality framework is out for consultation. This quality framework has a clear focus on career learning and career competence. This quality framework does not operate with pre-defined and normative learning goals, but has developed a model called 'Career learning in context' (Haug et al., 2019). This approach is inspired by other frameworks which use dichotomies such as 'positive uncertainty' and 'planned happenstance' (Gelatt \& Gelatt, 2003; Krumboltz, 2009) amongst others. This might be a sign of emerging counter discourses in career guidance.

\section{NORDIC COUNTER DISCOURSES}

In the Nordic countries we now see emerging discourses challenging the 'approaches drawing on human capital theory' and individualism, that have been present in relation to career guidance. Pre-defined and goal-oriented career competencies with concrete learning goals are challenged by counter-discourses that make use of methods associated with holistic, collectivistic and narrative approaches.

Discourses that challenge the growing individualisation of career guidance can be found in the methodological field. Thomsen (2012) criticises the tendency for 
career guidance to individualise societal issues, and her research has examined, from a participant perspective, how participants can move the guidance process from a private to a community focus, and how individual conversations can be transformed into more collective experiences. Valgreen (2013), provide examples of how life narratives can contribute to creating meaningful and coherent perspectives in lifelong career planning and development.

Kettunen (2017) is also challenging the individualisation within career guidance when she is introducing co-careering. Co-careering refers to shared expertise and meaningful co-construction on career issues that emerge and take place with and among community members (Haug, Hooley, Kettunen, \& Thomsen, Chapter 1, this volume; Kettunen, 2017, p. 47; Kettunen, Sampson, \& Vuorinen, 2015).

Neoliberal discourses are also challenged by discourses and methods that are value-based. Plant (2014) has argued for 'green guidance'. He questions onedimensional economic thinking and market principles and makes the case for an ecological awareness. Plant argues that the field of career guidance must challenge the paradigm that solely focuses on economic growth (Plant, 2014). He also claims that a Western middle-class mindset has clearly left its mark on the development of career theory and career guidance.

Finally a clear counter-discourse to the neoliberal discourse in career guidance can be observed internationally, for example in the work of Hooley, Sultana and Thomsen (2018) who focus on career guidance's role in social justice and emphasise learning and emancipation.

We are now in a period where Nordic researchers are challenging the dominant economic discourse drawing on human capital and individualisation. The different counter-discourses show that career guidance, to be relevant to the needs of people, has to be more than a technology for economic subjectivity.

\section{CAREER GUIDANCE; A HETEROGENEOUS IDENTITY}

This chapter has traced the discursive shifts that have taken place from the time of the establishment of modern career guidance, rooted in social work and philanthropy in an ethos of egalitarianism, solidarity, citizenship and harmony, to the dominant political and economic discourses of the 21 st century. Within Nordic countries we can observe a multitude of different discourses which are influencing career guidance and seeking to make it relevant to a diverse society.

The shifts in discourse that career guidance has gone through can be understood as belonging to five different societal periods. Yet, these discourses are all continuing to fight for hegemony and being challenged by new discourses that are emerging in Norway and other Nordic countries. As a result career guidance emerges with a heterogeneous identity, imbued by different ideologies influenced by economic, psychological, juridical and pedagogical discourses. 


\section{REFERENCES}

Alnæs, K. (1997). Historien om Norge. Under fremmed styre, Bind 2 [The history of Norway. Under foreign rule]. Oslo: Gyldendal Norsk Forlag.

Arbeidsdirektoratet. (2006). Management database. Retrieved from http://www.nsd.uib.no/polsys/data/ forvaltning/enhet/7805/endringshistorie

Australian Government. (2001). Australian blueprint for career development. Retrieved from https:/www.education.gov.au/australian-blueprint-career-development

Baune, T. A. (2007). Den skal tidlig krøkes [It should be raised early]. Oslo: Cappelen Akademisk Forlag.

Bengtsson, A. (2011). European policy of career guidance: The interrelationship between career selfmanagement and production of human capital in the knowledge economy. Policy Futures in Education, 9(5), 616-627. doi:10.2304/pfie.2011.9.5.616

Davis, J. B. (1914). Vocational and moral guidance. Boston, MA: Ginn.

Dean, M. (2010). Governmentality power and rule in modern society. London: Sage Publications.

European Commission. (2004). On strengthening policies, systems and practices in the field of guidance. Retrieved from http://register.consilium.europa.eu/doc/srv?l=EN\&f=ST\%209286\%202004\%20INIT

European Commission. (2008). On better integrating lifelong guidance into lifelong learning strategies. Retrieved from https://www.cedefop.europa.eu/en/news-and-press/news/council-resolution-betterintegrating-lifelong-guidance-lifelong-learning

Foucault, M. (1973). The order of things: An archaeology of the human sciences. New York, NY: Vintage Books.

Foucault, M. (2008). Sikkerhed, territorium, befolkning: Forelcesninger på Collège de France, 1977-1978 [Security, territory, population: Lectures on Collège de France 1977-1978]. Copenhagen: Hans Reizels Forlag.

Foucault, M., Martin, L. H., Gutman, H., \& Hutton, P. H. (1988). Technologies of the self: A seminar with michel foucault. Amherst, MA: University of Massachusetts Press.

Gelatt, H., \& Gelatt, C. (2003). Creative decision making using positive uncertainty. Boston, MA: Crisp Learning NETg.

Haug, E. H. (2018). Karrierekompetanser, karrierelcering og karriereundervisning: Hva, hvorfor, hvordan, for hvem og hvor? [Career skills, career learning and career education: What, why, how, for whom and where?] Bergen: Fagbokforlaget.

Haug, E. H., Holm-Nordhagen, A., Thomsen, R., Schulstok, T., Engh, L. W., Gravås, T. F., ... Gaarder, I. E. (2019). Nasjonalt kvalitetsrammeverk for karriereveiledning. Faglig forslag til områdene etikk, karrierekompetanse og kompetansestandarder [National quality framework for career guidance. Professional suggestion for ethics, career competence and competence standards]. Oslo: Kompetence Norge [Skills Norway]. Retrieved from https://www.kompetansenorge.no/globalassets/karriere/ rapport-nasjonalt-kvalitetsrammeverk-for-karriereveiledning.pdf

Hooley, T., Sultana, R., \& Thomsen, R. (2018). The neoliberal challenge to career guidance. In T. Hooley, R. Sultana, \& R. Thomsen (Eds.), Career guidance for social justice. Contesting neoliberalism (pp. 1-27). Abingdon, Oxon: Routledge.

Hooley, T., Watts, A. G., Sultana, R., \& Neary, S. (2013). The 'Blueprint' framework for career management skills: A critical exploration. British Journal of Guidance \& Counselling, 41, 117-131. doi:10.1080/03069885.2012.713908

Jones, L. K. (1994). Frank Parsons' contribution to career counseling. Journal of Career Development, 20(4), 287-294. doi:10.1007/bf02106301

Kettunen, J. (2017). Career practitioners' conceptions of social media and competency for social media in career services (Unpublished doctoral dissertation or master's thesis). University of Jyväskylä, Finnish Institute for Educational Research.

Kjærgård, R. (2012). Karriereveiledningens genealogi. Den suverene stats regulering av det frie utdannings- og yrkesvalg [Genealogy of career guidance. The regulation of the free educational and vocational choice] (Unpublished doctoral dissertation or master's thesis). Aarhus University, Denmark. 
Knoff, R. H. (1994). Psykologi i arbeid: Norsk arbeids-og organisasjonspsykologi før og nå [Psychology at work: Norwegian labor- and organisational psychology before and now]. In S. Reichelt (Ed.), Psykologi i forandring: Jubileumsbok: Norsk Psykologforening 60 år (pp. 189-206). Oslo: Norsk Psykologforening.

Kropotkin, P. A. (1909). The great French revolution, 1789-1793 (Vol. 1). London: W. Heinemann.

Krumboltz, J. D. (2009). The happenstance learning theory. Journal of Career Assessment, 17(2), 135154. doi:10.1177/1069072708328861

Mattsson, K. (1984). Yrkesvalsfrågan: Idéer och idétraditioner inom den statliga yrkesvägledningen för ungdom [Career choice question: Ideas and intellectual traditions within the state vocational guidance for youth] (Unpublished doctoral dissertation or master's thesis). Gleerup, Lund, Sweden.

Mik-Meyer, N., \& Villadsen, K. (2007). Magtens former: Sociologiske perspektiver på statens møde med borgeren [Sociological perspectives on the state's meeting with the citizen]. København: Hans Reitzels Forlag.

National Life/Work Centre. (n.d.). (1996). Blueprint for life/work designs. Retrieved from https://www.lifework.ca/BPframeworkoct00.PDF

National Occupational Information Coordinating Committee. (1989). National career development guidelines. Retrieved from https://associationdatabase.com/aws/NCDA/asset_manager/get_file/ 3384/ncdguidelines2007.pdf

NOU 1988:28. (1988). Med viten og vilje [With knowledge and will]. Oslo: Ministry of Education and Research. Retrieved from https://www.nb.no/items/URN:NBN:no-nb_digibok_2007081704023

NOU 2016:7. (2016). Norge i omstilling-karriereveiledning for individ og samfunn Norway in the changecareer guidance for individual and society. Oslo: Ministry of Education and Research. Retrieved from https://www.regjeringen.no/no/dokumenter/nou-2016-7/id2485246/

OECD. (2004). Career guidance: A handbook for policy makers. Paris: OECD.

OECD. (2014). OECD Skills strategy action report Norway. Retrieved from https://www.oecd.org/ skills/nationalskillsstrategies/OECD_Skills_Strategy_Action_Report_Norway.pdf

Papirbredden karrieresenter. (2014). Sjef $i$ eget liv [Boss in his own life]. Retrieved from https://karrierebuskerud.no/papirbredden_karrieresenter/sjef_i_eget_liv/

Plant, P. (2009). Faeste: Dansk uddannelses-og erhvervsvejledning, 1886-2009 [Footing: Danish educational and vocational counseling 1886-2009]. Fredensborg: Shultz.

Plant, P. (2014). Green guidance. In G. Arulmani, A. J. Bakshi, F. T. L. Leong, \& A. G. Watts (Eds.), Handbook of career development: International perspectives (pp. 309-317). New York, NY: Springer.

Riis, J. A. (1890). How the other half lives: Studies among the tenements of New York. New York, NY: Charles Scribner's Sons.

Rose, N. (1998). Inventing our selves: Psychology, power, and personhood. Cambridge: Cambridge University Press.

Røyland, S. (2011). Min utviklingsplan. Veiledning for larere og rådgivere [My development plan. Guidance for teachers and counselors]. Oslo: Pedlex Skoleinformasjon.

Savickas, M. L. (2008). Helping people choose jobs: A history of the guidance profession. In J. A. Athanasou \& R. Van Esbroeck (Eds.), International handbook of career guidance (pp. 97-113). Dordrecht: Springer.

Seville, C. (2017). Karrierelcering for unge [Career management skills]. Oslo: Pedlex.

Skills Development Scotland. (2012). Careers management skills framework. Retrieved from https://www.skillsdevelopmentscotland.co.uk/news-events/2012/june/careers-management-skillsframework/

St.meld. nr. 40. (1990-1991). Fra visjon til virke [From vision to action]. Oslo: Ministry of Education and Research. Retrieved from https://www.stortinget.no/no/Saker-og-publikasjoner/Stortingsforhandlinger/ Lesevisning/?p=1990-91\&paid=3\&wid=c\&psid=DIVL638\&s=True

Sultana, R. G. (2004). Guidance policies in the knowledge society: Trends, challenges and responses across Europe (Cedefop Panorama series; 85). Luxembourg: Office for Official Publications of the European Communities.

Super, P. (1929). Formative ideas in the YMCA. New York, NY: Association Press.

Svendsrud, A. (2011). Karriereverktøy [Career tools]. Retrieved from https://www.karriereverktoy.no 


\section{R. KJÆRGÅRD}

Svendsrud, A. (2015). Karriereveiledning $i$ et karrierelceringsperspektiv [Career guidance in a career learning perspective]. Oslo: Universitetsforlaget.

Sverdrup, J. (1884). Statsminister Sverdrups forslag til reform i vort folkskolevcesen og forhv: Statsraad N. Hertzbergs bemcerkninger til dette forslag [Prime minister Sverdrups proposal for reforming our primary school system]. Kristiania: De konservative foreningers centralstyrelse.

Søndergaard, D. M. (2000). Destabiliserende diskursanalyse: Veje ind i poststrukturalistisk inspireret empirisk forskning [Destabilizing discourse analysis: Roads into poststructuralist inspired empirical research]. In H. Haavind (Ed.), Kjønn og fortolkende metode: Metodiske muligheter i kvalitativ forskning (pp. 60-104). Oslo: Gyldendal Akademisk.

Thomsen, R. (2012). Career guidance in communities. Aarhus: Aarhus University Press.

Thomsen, R. (2014). Karrierekompetence og vejledning $i$ et nordisk perspektiv: Karrierevalg og karrierelcering. Oslo: Nordiskt Nätverk för Vuxnas Lärande (NVL).

Utdanningsdirektoratet. (2015). Lareplan for utdanningsvalg på ungdomstrinnet (UTV1-02) [Curriculum educational choice]. Oslo: The Norwegian Directorate for Education and Training. Retrieved from https://www.udir.no/k106/UTV1-02

Valgreen, H. (2013). Refleksion og fcellesskab - kollektiv narrativ praksis $i$ karrierevejledning [Reflection and community-Collective narrative practices in career guidance] (Unpublished doctoral dissertation or master's thesis). Aarhus University, Denmark.

Zytowski, D. G. (2001). Frank Parsons and the progressive movement. The Career Development Quarterly, 50(1), 57-65. doi:10.1002/j.2161-0045.2001.tb00890.x 